Sains Peternakan Vol. 14 (2), September 2016: 22-29

ISSN 1693-8828

\title{
Performan Produksi Kambing Saburai Jantan Pada Dua Wilayah Sumber Bibit di Kabupaten Tanggamus
}

\author{
Kusuma Adhianto, M. Dima Iqbal Hamdani, Sulastri dan Indah Listiana \\ Jurusan Peternakan Fakultas Pertanian Universitas Lampung \\ Jl. Prof. Dr. Soemantri Bojonegoro nomor 1 Bandar Lampung 35145 \\ Telp (0721) 701583, Fax. (0721) 770347, HP: 081227972696 \\ Contact person: Dr. Kusuma Adhianto, S.Pt., M.P. \\ E-mail: kusuma.adhianto@fp.unila.ac.id
}

\begin{abstract}
ABSTRAK
Kambing Saburai merupakan hasil perkawinan silang secara grading up antara kambing Boer jantan dan kambing Peranakan Etawah (PE) betina. Penelitian bertujuan untuk mengkaji performa produksi Kambing Saburai jantan pada dua wilayah sumber bibit yaitu di Kecamatan Gisting dan Sumberejo, Kabupaten Tanggamus, Provinsi Lampung. Penelitian dilakukan melalui metode survei dengan mengamati 90 ekor Kambing Saburai jantan di Kecamatan Gisting dan 90 ekor Kambing Saburai jantan di Kecamatan Sumberejo, Kabupaten Tanggamus, Provinsi Lampung. Sampel pengamatan ditentukan melalui metode purposive sampling. Peubah yang diukur meliputi bobot lahir (BL), bobot sapih (BS), bobot umur satu tahun (BSt), pertambahan bobot badan harian $(\mathrm{PBBH})$ prasapih dan pascasapih. Data hasil pengamatan di Kecamatan Gisting dan Kecamatan Sumberejo dianalisis menggunakan uji $t$-student. Hasil penelitian menunjukkan bahwa BL $(3,42 \pm 0,28 \mathrm{~kg})$, BS $(16,22 \pm 3,77 \mathrm{~kg})$, BSt $(36,56 \pm 4,85 \mathrm{~kg})$, PBBH prasapih $(140 \pm 0,04$ g/ekor/hari), PBBH pascasapih $(70 \pm 0,02$ g/ekor/hari). Kambing Saburai di Kecamatan Gisting berbeda tidak nyata $(\mathrm{P}>0,05)$ dengan Kambing Saburai di Kecamatan Sumberejo (BL 3,48 $\pm 0,41 \mathrm{~kg}$, BS $16,85 \pm 2,58 \mathrm{~kg}, \mathrm{BSt} 38,30 \pm 5,35 \mathrm{~kg}, \mathrm{PBBH}$ prasapih $150 \pm 0,03$ g/ekor/hari, $\mathrm{PBBH}$ pascasapih $80 \pm 0,02$ g/ekor/hari).
\end{abstract}

Kata kunci: performans produksi, kambing Saburai jantan, Tanggamus

\section{Performance Production Saburai Male Goat at Two Breeding Areas Resources Tanggamus Regency}

\begin{abstract}
Saburai goat was crossing breed by grading up between male Boer and female Ettawah grade goat. This research was conducted to compare production performance of male Saburai goat at Gisting subdistrict and Sumberejo subdistrict as Saburai goat breeding source area. Survey method were used in this research by observation to 90 at Gisting subdistrict and 90 at Sumberejo subdistrict tails male Saburai goat as sample. The sample were choosed by purposive sampling method. Variables observed were birth weight $(B W)$, weaning weight $(W W)$, yearling weight $(Y W)$, average of preweaning daily gain (APreDG), average of postweaning daily gain (APostDG). The data was analyzed by t-student test. Result of research indicated that $B W(3,42 \pm 0,28 \mathrm{~kg}), W W(16,22 \pm 3,77 \mathrm{~kg}), Y W(36,56 \pm 4,85 \mathrm{~kg})$, APreDG $(140,00 \pm 0,04$ $\mathrm{g} /$ tail/day), APostDG $(70,00 \pm 0,02 \mathrm{~g} /$ tail/day) of Saburai goat at Gisting subdistrict was not different

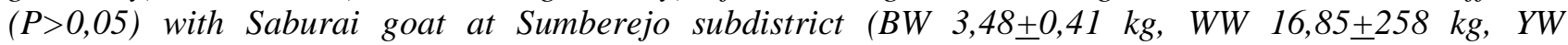

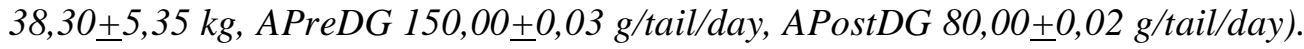

Keywords: performance production, Saburai male goat, Tanggamus 


\section{PENDAHULUAN}

Kambing merupakan ternak ruminansia kecil sumber protein hewani yang cukup potensial untuk dikembangkan sebagai penghasil daging dan susu. Kelebihan ternak kambing terletak pada kemampuan adaptasinya yang tinggi dengan berbagai kondisi lingkungan, potensi reproduksinya yang tinggi dan jumlah anak per kelahiran yang lebih dari satu ekor (Mahmilia, 2007). Kelebihan ternak kambing tersebut berpotensi untuk mendukung tercukupinya kebutuhan protein hewani yang terus meningkat seiring dengan meningkatnya jumlah penduduk Indonesia.

Provinsi Lampung tidak hanya unggul dalam populasi kambing tetapi juga memiliki tiga bangsa kambing lokal yang tersebar di semua kabupaten yaitu kambing Peranakan Etawah (PE), Rambon dan Kacang. Selain itu, terdapat Kambing Saburai yang merupakan bangsa baru yang saat ini baru berkembang di Kabupaten Tanggamaus (Sulastri et al., 2014).

Kambing Saburai merupakan hasil persilangan grading up antara kambing Boer jantan dan kambing PE betina. Dua lokasi di Kabupaten Tanggamus yang ditetapkan sebagai wilayah pengembangan kambing Saburai adalah Kecamatan Gisting dan Sumberejo.

Kambing Saburai adalah salah satu jenis kambing yang banyak dipelihara oleh peternak di Kabupaten Tanggamus, melalui SK Menteri Pertanian No 359/Kpts/PK.040/6/2015 tanggal 8 Juni 2015 kambing Saburai telah ditetapkan sebagai salah satu plasma nutfah Indonesia yang harus dijaga, ditingkatkan dan dikembangkan populasinya sehingga dapat memberi banyak manfaat bagi peternak dan juga dalam upaya mencukupi kebutuhan daging, baik tingkat lokal dan nasional. Kambing Saburai memiliki keunggulan antara lain pemeliharaan yang mudah, memiliki kemampuan beradaptasi tinggi terhadap berbagai keadaan lingkungan dan tingkat pertumbuhan yang tinggi. Salah satu upaya yang dilaksanakan untuk mengembangkan usaha peternakan kambing Saburai yang sudah ada yakni meneliti tentang pola pertumbuhan kambing Saburai melalui bobot tubuhnya yang dapat memudahkan peternak dalam menentukan nilai ekonomis dari ternaknya (Adhianto et al., 2015).

Wilayah yang ditetapkan sebagai lokasi pengembangan kambing Saburai berkewajiban meningkatkan populasi dan produktivitas kambing Saburai yang dikelolanya. Peningkatan populasi dan produktivitas kambing dapat ditempuh melalui seleksi. Performa yang menjadi sasaran seleksi pada kambing tipe pedaging seperti kambing Saburai antara lain pertumbuhan prasapih, bobot umur satu tahun (Sulastri dan Sumadi, 2002), bobot sapih dan pertumbuhan pascasapih (Hardjosubroto, 1994).

Seleksi merupakan tindakan untuk memilih calon ternak jantan atau betina yang akan dikembangbiakkan dalam suatu wilayah. Kambing jantan maupun betina terpilih diharapkan mewariskan keunggulan genetik kinerjanya masing-masing separuh pada keturunannya. Kambing jantan mampu mewariskan kinerjanya pada lebih banyak keturunan karena dapat mengawini banyak kambing betina dalam kurun waktu tertentu sedangkan kambing betina hanya mampu mewariskan pada satu sampai 3 ekor anak perkelahiran (Hardjosubroto, 1994).

Performa produksi kambing dipengaruhi oleh faktor genetik dan lingkungan. Kambing-kambing Saburai jantan yang dikembangkan di Kecamatan Gisting dan Sumberejo dapat menunjukkan performa produksi yang sama atau berbeda karena kesamaan atau perbedaan faktor genetik dan lingkungan yang memengaruhinya. Berdasarkan kondisi tersebut, maka dilakukan penelitian untuk mengetahui performans produksi kambing jantan yang dikembangbiakkan di Kecamatan Gisting dan Sumberejo. 


\section{MATERI DAN METODE}

\section{Alat dan Bahan}

Materi penelitian yang digunakan yaitu 90 ekor Kambing Saburai jantan di Kecamatan Gisting dan 90 ekor Kambing Saburai jantan di Kecamatan Sumberejo, Kabupaten Tanggamus, Provinsi Lampung.
Sampel pengamatan ditentukan dengan metode purposive sampling.

Alat yang digunakan dalam penelitian ini yaitu timbangan merk Oxone ${ }^{\circledR}$ kapasitas $120 \mathrm{~kg}$ dengan ketelitian $0,1 \mathrm{~kg}$, alat tulis dan kamera digital. Rincian umur dan jumlah kambing yang digunakan sebagai materi penelitian terdapat pada Tabel 1 .

Tabel 1. Jumlah Kambing Saburai Jantan yang Digunakan Sebagai Materi Penelitian

\begin{tabular}{lll}
\hline \multicolumn{2}{l}{ Jumlah Kambing } & \\
\hline Umur & Kecamatan Gisting & Kecamatan Sumberejo \\
\hline Lahir & 30 ekor & 30 ekor \\
Sapih & 30 ekor & 30 ekor \\
1 tahun & 30 ekor & 30 ekor \\
\hline
\end{tabular}

\section{Metode Penelitian}

Penelitian dilakukan dengan metode survei. Data yang diambil adalah data primer dan sekunder. Data primer diperoleh dengan cara menimbang tubuh kambing secara langsung oleh peneliti. Data sekunder diperoleh dari hasil pengukuran dan penimbangan yang dilakukan peternak terhadap kambing yang diamati dan direkam dalam kartu recording.

\section{Peubah yang Diamati}

a. Bobot lahir (BL)

Bobot lahir diperoleh dengan cara menimbang anak kambing sesaat setelah lahir dengan batas maksimal penimbangan 24 jam setelah anak kambing dilahirkan.

b. Bobot sapih (BS)

Bobot sapih diperoleh dengan cara menimbang anak kambing sesaat setelah disapih dari induknya pada umur 3 sampai 4 bulan. c. Bobot umur satu tahun (BSt)

Bobot umur satu tahun diperoleh dengan cara menimbang kambing pada umur 12 bulan dan dibantu dengan melihat kondisi poel gigi.

d. Pertambahan bobot badan harian

Pertambahan bobot badan harian $(\mathrm{PBBH})$ prasapih dan pascasapih dihitung dengan rumus sebagai berikut:

$\mathrm{PBBH}$ prasapih $=\frac{\mathrm{BS}-\mathrm{BL}}{90}$

Keterangan:

$\mathrm{BS}=$ bobot sapih

$\mathrm{BL}=$ bobot lahir

$90=$ umur sapih (hari)

$\mathrm{PBBH}$ pascasapih $=\frac{\mathrm{BSt}-\mathrm{BS}}{275}$

Keterangan:

$\mathrm{BSt}=$ bobot umur satu tahun sapih

$\mathrm{BS}=$ bobot sapih

275= tenggang waktu antara umur sapih (90 hari) dengan umur satu tahun (365 hari) 


\section{Analisis Data}

Data bobot lahir, bobot sapih dan bobot umur satu tahun kambing Saburai jantan di Kecamatan Gisting dan Sumberejo disajikan dalam bentuk tabel dan dianalisis dengan uji $t$-student pada taraf nyata $5 \%$ sesuai dengan rekomendasi Nazir (1985) untuk membandingkan bobot lahir (BL), bobot sapih (BS) dan bobot umur satu tahun (BSt) Kambing Saburai di Kecamatan Gisting dan Kecamatan Sumberejo.

\section{HASIL DAN PEMBAHASAN}

Tabel 2. Performa produksi Kambing Saburai jantan di Kecamatan Gisting dan Sumberejo.

\begin{tabular}{lllll}
\hline \multirow{2}{*}{\multicolumn{1}{c}{ Peubah }} & \multicolumn{2}{l}{ Kecamatan Gisting } & \multicolumn{2}{l}{ Kecamatan Sumberejo } \\
\cline { 2 - 5 } & Rata-rata & Kisaran & Rata-rata & Kisaran \\
\hline Bobot lahir $(\mathrm{kg})$ & $3,42 \pm 0,28$ & $3,00-4,00$ & $3,48 \pm 0,41$ & $2,50-4,60$ \\
Bobot sapih $(\mathrm{kg})$ & $16,22 \pm 3,77$ & $9,00-22,30$ & $16,85 \pm 2,58$ & $10,00-20,80$ \\
Bobot setahun (kg) & $36,56 \pm 4,85$ & $27,00-48,00$ & $38,30 \pm 5,35$ & $26,00-46,10$ \\
PBBH prasapih (g/ekor/hari) & $140 \pm 0,04$ & $60-200$ & $150 \pm 0,03$ & $80-200$ \\
PBBH pascasapih (g/ekor/hari) & $70 \pm 0,02$ & $20-110$ & $80 \pm 0,02$ & $40-110$ \\
\hline
\end{tabular}

\section{Manajemen Perkandangan}

Kandang kambing yang ada di Kecamatan Gisting dan Sumberejo berupa kandang panggung dengan sistem pemeliharaan individu dan dipisahkan oleh sekat. Hal tersebut sesuai dengan pendapat Roger dan Subandriyo (1997) bahwa kandang panggung sangat baik untuk memelihara kambing karena kambing tidak bersentuhan langsung dengan kotorannya sehingga akan merasa nyaman.

Lantai kandang kambing yang ideal adalah yang berbahan kayu atau bambu yang kuat dengan jarak antar kayu sekitar $1 \mathrm{~cm}$. Bahan atap yang digunakan yaitu genting. Bahan kandang yang digunakan sesuai dengan pendapat Roger dan Subandriyo (1997) bahwa bahan pembuat kandang harus yang mudah didapat dilokasi, tidak mahal dan tahan terhadap serangan serangga.

\section{Manajemen Pemberian Pakan dan Air Minum}

Pakan yang diberikan pada kambing di Kecamatan Gisting dan Sumberejo hampir sama yaitu berupa hijauan ramban (lamtoro, gamal, waru dan daun mahoni) dan limbah perkebunan (pisang, singkong, kakao dan kopi). Menurut Mulyono dan Sarwono (2008) pada dasarnya kambing tidak selektif dalam memilih pakan. Segala macam daun-daunan dan rumput disukai, tetapi hijauan dari daundaunan lebih disukai daripada rumput.

\section{Manajemen Kesehatan}

Manajemen kesehatan kambing di Kecamatan Gisting dan Sumberejo tidak banyak mendapat perhatian serius kecuali pemberian obat cacing setiap dua bulan sekali pada kambing-kambing di lokasi penelitian. Kambing-kambing di lokasi penelitian jarang terserang penyakit. Hal tersebut dibuktikan dengan rendahnya tingkat kematian anak kambing di Kecamatan Sumberejo 0,19\% (Sulastri et al., 2014). Manajemen kesehatan yang diterapkan peternak di lokasi penelitian 
berupa tindakan pencegahan seperti pemberian obat cacing.

\section{Bobot Lahir}

Rata-rata bobot lahir Kambing Saburai jantan di Kecamatan Gisting dan Sumberejo (Tabel 2) menunjukkan bahwa rata-rata bobot lahir Kambing Saburai jantan di Kecamatan Gisting $(3,42 \pm 0,28 \mathrm{~kg})$ berbeda tidak nyata $(\mathrm{P}>0,05)$ dengan Kecamatan Sumberejo $(3,48 \pm 0,41 \mathrm{~kg})$. Hal tersebut disebabkan oleh rendahnya keragaman genetik dan fenotipik bobot lahir tetua jantan dan betina kambing Saburai di dua lokasi penelitian.

Umur induk juga memengaruhi bobot lahir anak kambing. Induk yang masih muda dan belum mencapai dewasa tubuh pada umumnya melahirkan anak kambing dengan bobot lahir yang rendah karena antara induk dan anak terjadi kompetisi untuk memperoleh nutrisi dari bahan pakan yang dikonsumsi induknya. Tipe kelahiran juga salah satu faktor yang memengaruhi bobot lahir ternak. Tipe kelahiran tunggal akan menghasilkan bobot lahir yang lebih tinggi dibandingkan dengan kembar dua atau tiga (Nurgiartiningsih et al., 2006; Nasich, 2011). Hal ini karena pada tipe kelahiran tunggal anak kambing mendapatkan sepenuhnya nutrisi pakan dari induk ketika bunting. Sehingga perkembangan janin pada rahim induk akan lebih baik pada tipe kelahiran tunggal.

Menurut Anggorodi

menyatakan bahwa bobot lahir dipengaruhi oleh jenis kelamin anak, bangsa induk, lama bunting, umur induk dan makanan induk selama bunting. Pendapat tersebut sejalan dengan pendapat Rivai (1995) yang menyatakan bahwa bobot lahir juga dipengaruhi oleh faktor-faktor yang dimiliki oleh induk seperti genetik induk, manajemen terhadap induk dan paling dominan adalah pemberian makanan selama bunting.

Rata-rata bobot lahir kambing Saburai hasil penelitian ini (Kecamatan Gisting
$3,42 \pm 0,28 \mathrm{~kg}$ dan Kecamatan Sumberejo $3,48 \pm 0,41 \mathrm{~kg}$ ) lebih tinggi daripada $2,9 \mathrm{~kg}$ (Adhianto dan Sulastri, 2007) dan 3,02+0,29 $\mathrm{kg}$ (Adhianto et al., 2012) pada anak kambing Boerawa yang merupakan cikal bakal kambing Saburai. Terjadinya peningkatan bobot lahir dari anak kambing Saburai dari tahun ke tahun menggambarkan semakin baiknya manajemen dalam budidaya kambing Saburai di Kabupaten Tanggamus.

\section{Bobot Sapih}

Hasil penelitian menunjukkan bahwa rata-rata bobot sapih Kambing Saburai jantan (Tabel 2) di Kecamatan Gisting (16,22+3,77 $\mathrm{kg})$ berbeda tidak nyata $(\mathrm{P}>0,05)$ dengan Kambing Saburai jantan di Kecamatan Sumberejo $(16,85 \pm 2,58 \mathrm{~kg})$. Bobot sapih anak kambing Saburai yang berbeda tidak nyata tersebut disebabkan oleh kuantitas dan kualitas pakan yang diberikan pada induk di kedua lokasi penelitian adalah sama. Gatenby et al. (1994) menyatakan bahwa nutrisi yang terdapat dalam pakan memengaruhi kualitas susu yang dikonsumsi induk.

Tipe kelahiran juga dapat berpengaruh terhadap bobot sapih. Subandriyo (1996) menyatakan bahwa bobot sapih sangat dipengaruhi tipe kelahirannya, hal ini disebabkan terbatasnya produksi susu induk sehingga apabila induk mempunyai anak kembar maka jumlah susu yang terbatas tersebut harus dibagi ke anaknya.

Rata-rata bobot sapih Kambing Saburai jantan hasil penelitian ini (Kecamatan Gisting 16,22 $\pm 3,77 \mathrm{~kg}$, Kecamatan Sumberejo $16,85 \pm 2,58 \mathrm{~kg}$ ) lebih rendah daripada hasil penelitian Sulastri (2014) yaitu 19,67+1,54. Perbedaan hasil penelitian ini dengan laporan Sulastri (2014) disebabkan oleh perbedaan mutu genetik, budidaya dan lingkungan lokasi kambing berada. Sejalan dengan Acker (1988) yang menyatakan bahwa pertumbuhan prasapih bergantung pada kemampuan induk dalam memberikan susu. Menurut Edey (1983), bobot sapih dipengaruhi oleh faktor 
genetik, bobot lahir, produksi susu induk, litter size, umur induk, jenis kelamin anak dan paritas.

\section{Bobot Satu Tahun}

Hasil penelitian menunjukkan bahwa rata-rata bobot umur satu tahun kambing Saburai jantan (Tabel 2) di Kecamatan Gisting $(36,56+4,85 \mathrm{~kg})$ berbeda tidak nyata $(\mathrm{P}>0,05)$ dengan Kambing Saburai jantan di Kecamatan Sumberejo $(38,30+5,35 \mathrm{~kg})$. Manajemen pemelihaaan Kambing pascasapih di kedua lokasi penelitian sama. Kandang sama-sama berbentuk panggung, beratap genting, berdinding bilah kayu dan kambing ditempatkan dalam ruangan individual. Menurut Hardjosubroto (1994), pertumbuhan pascasapih lebih mencerminkan kepada kemampuan anak untuk tumbuh berdasarkan potensi genetiknya yaitu potensi pertumbuhan dari masing-masing individu ternak dan pakan yang tersedia.

Rata-rata bobot umur satu tahun Kambing Saburai jantan hasil penelitian ini (Kecamatan Gisting, Kecamatan Sumberejo $36,56 \pm 4,85 \mathrm{~kg}$ dan $38,30 \pm 5,35 \mathrm{~kg}$ ) lebih rendah daripada hasil peneltian Sulastri et al. (2014) yaitu 42,27 kg. Edey (1983) menyatakan bahwa faktor-faktor yang memengaruhi pertumbuhan pascasapih yaitu nutrisi, jenis kelamin, genetik, umur, bobot sapih dan lingkungan.

\section{Pertambahan Bobot Badan Harian (PBBH)}

Pada penelitian ini menunjukkan bahwa rata-rata bobot badan harian prasapih kambing Saburai jantan di Kecamatan Gisting $(140 \pm 0,04 \mathrm{~g} / \mathrm{ekor} / \mathrm{hari})$ berbeda tidak nyata ( $>00,05)$ dengan di Kecamatan Sumberejo $(150 \pm 0,03$ g/ekor/hari). Pertambahan bobot badan harian $(\mathrm{PBBH})$ prasapih dipengaruhi oleh induknya. Hal ini karena kuantitas dan kualitas susu dari induk yang dikonsumsi kambing merupakan satu-satunya nutrisi yang masuk ke dalam tubuh kambing sebelum disapih.
Rata-rata $\mathrm{PBBH}$ prasapih kambing Saburai jantan pada penelitian ini $(140 \pm 0,04$ g/ekor/hari dan 150 $\pm 0,03$ g/ekor/hari) lebih rendah dibandingkan pada penelitian Dakhlan et al. (2011) bahwa PBBH prasapih kambing Boerawa sebesar 183 g/ekor/hari. Hal ini dapat disebabkan karena perbedaan kualitas genetik pada kambing.

Selain itu, hasil penelitian menunjukkan bahwa $\mathrm{PBBH}$ pascasapih kambing Saburai jantan di Kecamatan Gisting $(70 \pm 0,02 \mathrm{~g} / \mathrm{ekor} / \mathrm{hari})$ berbeda tidak nyata ( $\mathrm{P}>0,05)$ daripada di Kecamatan Sumberejo

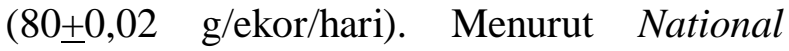
Research Council (1985), pertambahan bobot badan dipengaruhi oleh beberapa faktor yaitu total protein yang diperoleh setiap harinya, jenis kelamin, umur, keadaan genetis, lingkungan, kondisi setiap individu dan manajemen. Menurut Hatmono dan Hastoro (1997), dilihat dari pertambahan bobot badan harian maka akan diketahui kualitas bahan pakan ternak. Mathius et al. (1996) juga menyatakan bahwa pertambahan bobot badan harian ternak ruminansia sangat dipengaruhi oleh kualitas dan kuantitas pakan.

Rata-rata bobot badan harian pascasapih kambing Saburai jantan di lokasi penelitian $(70 \pm 0,02$ g/ekor/hari dan $80 \pm 0,02 \mathrm{~g} / \mathrm{ekor} / \mathrm{hari})$ lebih tinggi dibandingkan dengan penelitian Dakhlan et al. (2011) bahwa pertambahan bobot badan harian (PBBH) pascasapih Kambing Boerawa sebesar 58 g/ekor/hari. Perbaikan manajemen pemeliharaan yang terus diupayakan oleh peternak memberikan dampak perbedaan pertambahan bobot badan harian pascasapih.

\section{KESIMPULAN}

Berdasarkan penelitian yang telah dilakukan dapat disimpulkan bahwa rata-rata bobot lahir, bobot sapih, bobot umur satu tahun, $\mathrm{PBBH}$ prasapih dan $\mathrm{PBBH}$ pascasapih kambing Saburai jantan di Kecamatan Sumberejo $(3,42 \pm 0,28 \mathrm{~kg}, 16,22 \pm 3,77 \mathrm{~kg}$, $36,56 \pm 4,85 \mathrm{~kg}, 140 \pm 0,04 \mathrm{~g} /$ ekor/hari dan 
$70 \pm 0,02$ g/ekor/hari) masing-masing berbeda tidak nyata $(\mathrm{P}>0,05)$ dengan di Kecamatan Gisting $(3,48+0,41 \mathrm{~kg}, \quad 16,85+2,58 \mathrm{~kg}$, $38,30+5,35 \mathrm{~kg}, 150+0,03 \mathrm{~g} / \mathrm{ekor} / \mathrm{hari}$ dan $80+0,02$ g/ekor/hari).

\section{DAFTAR PUSTAKA}

Acker, D. 1988. Animal Science and Industry. Prentice Hall Inc., Anglewood Cliffs, New Jersey.

Adhianto, K. dan Sulastri 2007. Evaluasi Performan Produksi Kambing Peranakan Ettawa dan Boerawa Pada Sistem Pemeliharaan di Pedesaaan. Jurnal Agritek 15 (3): 504-506.

Adhianto, K., N. Ngadiyono, Kustantinah dan I. G.S. Budisatria. 2012. Lama Kebuntingan, Litter Size dan Bobot Lahir Kambing Boerawa pada Pemeliharaan Perdesaan di Kecamatan Gisting Kabupaten Tanggamus. Jurnal Penelitian Pertanian Terapan Vol. 12 (2): 131-136.

Adhianto, K., M.D. Iqbal Hamdani dan Sulastri. 2015. Model Kurva Pertumbuhan Pra Sapih Kambing Saburai di Kabupaten Tanggamus. Jurnal Sains Peternakan Indonesia. 10: 2: 95-100.

Anggorodi, R. 1979. Ilmu Makanan Ternak Umum. PT Gramedia Pustaka. Jakarta.

Edey, T.N. 1983. The genetic pool of sheep and goats. In: Tropical Sheep and Goat Production (Edited by Edey. T.N.). Australia University International, Development Program, Canberra. pp.3-5.

Dakhlan, A., I. Harris dan S. Suharyati. 2011. Performan produksi dan reproduksi Kambing Boerawa dan Boercang grade-2 dengan pakan berbeda. Prosiding Seminar Nasional Sains dan Teknologi IV: 211-227. Hotel Marcopolo, Bandar Lampung, 29-30 November 2011.
Gatenby, R.M., G.E. Bradford, Ralaksanto, E. Romjali, A.D. Pitono and H. Sakul. 1994. Growth, mortality and wool cover of Sumatera sheep and cross within Virgin Island, Barbados Blackbelly and Javanes fat tailbreed. Working paper 153. CRSP, Balai Penelitian Ternak, Bogor.

Hardjosubroto, W. 1994. Aplikasi Pemuliabiakan Ternak di Lapangan. PT Grasindo. Jakarta.

Hatmono, H. dan Hastoro, I. 1997. Urea Mollases Blok, Pakan Suplemen Ternak Ruminansia. PT Trubus Agriwidya. Unggaran.

Mahmilia, F. 2007. Penampilan reproduksi kambing induk: Boer dan Kacang yang disilangkan dengan pejantan Boer. Prosiding Seminar Nasional Teknologi Peternakan dan Veteriner 2007: 485490.

Mathius, I.W.M. Martawidjaja, A. Wilson dan T. Manurung. 1996. Strategi kebutuhan energy-protein untuk domba lokal: I. Fase pertumbuhan. Ilmu Ternak dan Veteriner. 2: 84-91.

Mulyono, S. dan B. Sarwono. 2008. Penggemukan Kambing Potong. Penebar Swadaya. Jakarta.

Nasich, M. 2011. Produktivitas kambing hasil persilangan antara pejantan Boer dengan induk lokal (PE) periode prasapih. J. Ternak Tropika Vol. 12, No.1. 56-62.

National Research Council. 1985. Nutrient Riquirement of Sheep. Six received edition. National Academy of Science. Washington DC.

Nazir, M. 1985. Metode Penelitian. Ghalia Indonesia. 325-382.

Nurgiartiningsih, V.M.A., A. Budiarto, G. Ciptadi, T. Joharyani, M. Nasich and Subagiyo. 2006. Birth weight and litter size of crossbred Boer and local Indonesia goat. Proceeding of the 4th ISTAP Animal Production and Sustainable and Agriculture in the 
Tropic. Faculty of Animal Science. Gadjah Mada University. November 2006. pp. 422-425.

Rivai, M. 1995. Ilmu Reproduksi Ternak Potong dan Kerja. Diktat. Fakultas Peternakan, Universitas Andalas. Padang.

Roger C.M. dan Subandriyo. 1997. Sheep and goat production handbook for Southeast Asia. Davis: Small Ruminant-Collaborative Reserch Support Program, University of California Davi.

Subandriyo. 1996. The Small Ruminant CRSP In Indonesia 1980-1993, Achievements And Impact. Small Ruminant Workshop Proceedings. Humid Tropics; Hair Sheep And Integration Of Sheep Into Tree Crop Plantation. 57-65.
Sulastri. 2007. Estimasi parameter genetik sifat pertumbuhan Kambing Boerawa di Desa Campang, Kecamatan Gisting, Kabupaten Tanggamus. Pustaka Ilmiah Universitas Lampung. Bandar Lampung.

Sulastri, Sumadi, T. Hartatik dan N. Ngadiyono. 2014. Performans pertumbuhan Kambing Boerawa di Village Breeding Centre, Desa Dadapan, Kecamatan Sumberejo, Kabupaten Tanggamus, Provinsi Lampung. Sains Peternakan Vol. 12 (1), Maret 2014: 1-9. ISSN 1693-8828.

Sulastri, Sumadi dan W. Hardjosubroto. 2002. Estimasi parameter genetik sifat-sifat pertumbuhan kambing Peranakan Etawah di Unit Pelaksana Teknis Ternak Singosari, Malang, Jawa Timur. Agrosains 15 (3): 431-442. 